\title{
Kemampuan Bacillus subtilis dan Trichoderma harzianum dalam Campuran Serat Karbon dan Silika Nano untuk Meningkatkan Ketahanan Tanaman Padi terhadap Penyakit Blas (Pyricularia oryzae)
}

\author{
Hersanti $^{1 *}$, Nurul Safitri ${ }^{2}$, Luciana Djaya ${ }^{1}$ dan Martua Suhunan Sianipar ${ }^{1}$ \\ ${ }^{1}$ Departemen Hama dan Penyakit Tumbuhan, Fakultas Pertanian, Universitas Padjadjaran \\ Jl. Raya Bandung Sumedang km 21, Jatinangor \\ ${ }^{2}$ Mahasiswa Fakultas Pertanian, Universitas Padjadjaran \\ *Alamat Korespondensi: hersanti@unpad.ac.id
}

\begin{abstract}
Ability of Bacillus subtilis and Trichoderma harzianum formulated with carbon fiber and nano silica to increase rice resistance to blast disease (Pyricularia oryzae)

Blast disease caused by Pyricularia oryzae is one of the important diseases on paddy rice in Indonesia. Biocontrol agents can be used to control the disease. In this experiment Bacillus subtilis and Trichoderma harzianum were formulated with carbon fiber as the carrier and enriched with nano silica as a plant micro nutrient. The study was objected to find out the ability of single and combination of B. subtilis and T. harzianum, formulated with and without carbon fiber and nano silica, to increase rice resistance to blast disease. The formulations were applied twice, first by soaking the rice seeds, and second by soaking the roots of seedlings in eight formulation treatments. The experiment was arranged in the randomized block design. The results showed that both single and combination of B. subtilis and T. harzianum was able to increase the resistance of rice plants to blast disease, with $15.64 \%$ to $21.59 \%$ inhibition of blast disease. The single and combination of B. subtilis and T. harzianum with carbon fiber and nano silica were able to increase the resistance of rice to blast disease, with $18.75 \%$ to $25.12 \%$ inhibition of blast disease.
\end{abstract}

Keywords: Antagonistic agents, Biocontrol delivery system, Endophytic bacteria, PGPF, Pyricularia oryzae

\begin{abstract}
ABSTRAK
Penyakit blas yang disebabkan Pyricularia oryzae merupakan salah satu penyakit penting pada tanaman padi di Indonesia. Pengendalian yang dapat digunakan untuk mengendalikan penyakit blas ialah menggunakan agens biokontrol. Dalam penelitian ini bakteri Bacillus subtilis dan jamur Trichoderma harzianum diformulasikan dengan bahan pembawa berupa serat karbon dan diperkaya dengan unsur hara mikro berupa silika dalam ukuran nano. Penelitian ini dilakukan untuk menguji kemampuan $B$. subtilis dan T. harzianum yang diaplikasikan secara tunggal maupun kombinasi, dengan dan tanpa campuran serat karbon dan silika nano, dalam meningkatkan ketahanan tanaman padi terhadap penyakit blas. Pengujian pada tanaman padi dilakukan dengan merendam benih dan akar semai padi dalam delapan perlakuan formulasi. Percobaan disusun menggunakan rancangan acak kelompok. Hasil percobaan menunjukkan bahwa aplikasi $B$. subtilis dan $T$. harzianum, baik secara tunggal maupun kombinasi, mampu meningkatkan ketahanan tanaman padi terhadap penyakit blas dengan penghambatan penyakit berkisar antara $15,64 \%$ - 21,59\%. Selain itu, aplikasi tunggal maupun kombinasi $B$. subtilis dan $T$. harzianum yang diformulasikan dengan serat karbon dan silika nano mampu meningkatkan ketahanan tanaman padi terhadap penyakit blas, dengan penghambatan penyakit berkisar antara $18,75 \%-25,12 \%$.
\end{abstract}

Kata Kunci: Agens antagonis, Bakteri endofit, Biokontrol, PGPF, Pyricularia oryzae 


\section{PENDAHULUAN}

Salah satu penyakit pada tanaman padi yang menyebabkan penurunan hasil ialah penyakit blas yang disebabkan oleh jamur Pyricularia oryzae. Penurunan hasil tanaman padi yang disebabkan penyakit blas di Filipina berkisar antara 50-85\% dan di Vietnam berkisar 38-83\% (Wang et al., 2014). Menurut Suganda dkk. (2016) potensi kehilangan hasil tanaman padi di wilayah endemik blas di Indonesia yaitu sebesar $61 \%$ atau setara dengan 3,65 ton/ha. Cara pengendalian yang umum dilakukan untuk penyakit blas ialah penggunaan fungisida. Selain menggunakan fungisida, pengendalian penyakit tanaman dapat dilakukan juga dengan menggunakan varietas tahan. Belum banyak varietas padi yang tahan terhadap penyakit blas. Kendala utama dalam penggunaan varietas padi tahan penyakit blas menurut Santoso dkk. (2007) adalah Jamur $P$. oryzae memiliki kemampuan rekombinasi gen yang dapat dilakukan secara seksual maupun aseksual, sehingga mampu menghasilkan ras baru yang dapat mematahkan ketahanan tanaman. Hal ini membuat pengendalian menggunakan varietas tahan hanya dapat bertahan 2-4 musim tanam. Pengendalian yang masih efektif untuk penyakit blas adalah penggunaan fungisida (Suganda dkk., 2016). Penggunaan fungisida akan meningkatkan biaya produksi dan menimbulkan dampak negatif bagi lingkungan dan kesehatan manusia. Pengendalian secara biologi dapat dijadikan sebagai alternatif pengendalian $P$. oryzae, dengan menggunakan agens hayati yang mampu meningkatkan ketahanan tanaman terhadap patogen.

Peningkatan ketahanan inang terhadap patogen dapat dilakukan dengan induksi. Ketahanan terinduksi menyebabkan kondisi fisiologis yang mengatur sistem ketahanan tanaman inang menjadi aktif (Zhang et al., 2007). Ketahanan terinduksi dapat distimulasi menggunakan induser biotik dan induser abiotik. Induser biotik dapat berupa mikroorganisme avirulen, nonpatogenik dan saprofit yang mampu memroduksi senyawa kimia (elisitor) yang dapat meningkatkan ketahanan tanaman. Induser abiotik dapat berupa asam salisilat dan asam kloroetil fosfonat (Djaenuddin, 2016).

Beberapa mikroba yang dapat menginduksi ketahanan tanaman ialah Bacillus subtilis dan Trichoderma harzianum. Bacillus spp. mampu menginduksi terbentuknya metabolit sekunder yang dapat meningkatkan ketahanan tanaman terhadap penyakit bercak daun, mati kecambah dan penyakit hawar daun, melalui mekanisme induksi resistensi (Djaenuddin, 2016). Menurut Parida dkk. (2016) B. subtilis merupakan bakteri endofit tanaman padi yang mampu meningkatkan hasil dan juga meningkatkan ketahanan tanaman padi terhadap penyakit hawar daun bakteri. Jamur T. harzianum merupakan Plant Growth Promoting Fungus (PGPF) yang mampu menginduksi ketahanan tanaman dan mengurangi kejadian penyakit busuk akar yang disebabkan oleh Macrophomina phaseolina pada tanaman kacang tanah (Sreedevi et al., 2011). Kemampuan mikroba antagonis dalam menghambat pertumbuhan patogen dapat ditingkatkan melalui konsorsium mikroba. Konsorsium merupakan pencampuran dua jenis mikroba atau lebih untuk meningkatkan kemampuan mikroba antagonis dalam menghambat pertumbuhan patogen (Grosch et al., 2011). Aplikasi mikroba antagonis secara konsorsium diharapkan memberikan hasil yang lebih baik dibandingkan dengan aplikasi mikroba secara tunggal (Komarwidjaja, 2009).

Penggunaan agens hayati sebagai pengendali penyakit tumbuhan akan lebih mudah diaplikasikan dalam bentuk formulasi. Formulasi biopestisida dibuat untuk memertahankan kondisi mikroba antagonis yang dijadikan sebagai agens biokontrol agar tetap viabel dan stabil, serta untuk mempermudah aplikasi di lapangan (Nawangsih dkk., 2015). Agens hayati yang dapat digunakan untuk mengendalikan penyakit blas yang disebabkan Magnaporthe grisea (fase seksual dari $P$. oryzae) pada tanaman padi ialah $B$. subtilis dan Trichoderma spp. (Ali \& Nadarajah, 2014). Bahan pembawa dalam formulasi agens biokontrol yang baru dikembangkan yaitu serat karbon 80 mesh. Serat karbon 80 mesh memiliki permukaan yang luas, yang dapat dijadikan tempat menempelnya mikroba. Menurut Aida (2016) Pseudomonas fluorescens tetap viabel setelah disimpan 7 hari pada formulasi dengan bahan pembawa serat karbon. Salah satu bahan pelengkap dalam formulasi adalah hara mikro berupa silika berukuran nano. Silika nano lebih mudah untuk diserap tanaman dan hara silika mampu mempertebal dinding sel tanaman (Karunakaran et al., 2013).

Ruhyaman et al. (2017) menyatakan campuran suspensi serat karbon 80 mesh dengan konsentrasi 5\% dan suspesi silika nano dengan konsentrasi 3\% merupakan perlakuan terbaik yang mampu memertahankan viabilitas $B$. subtilis. Campuran tersebut mampu meningkatkan kemampuan $B$. subtilis untuk menekan patogen Ralstonia solanacearum. Jamur T. harzianum dalam campuran 
serat karbon 80 mesh dan silika nano 1\% mampu menekan pertumbuhan Phytophthora nicotianae secara in-vitro (Hersanti \& Djaya, 2019). Menurut Hersanti dkk. (2019) B subtilis dan Lysinibacillus sp. dalam campuran serat karbon dan silika nano $3 \%$ mampu menginduksi ketahanan tanaman bawang merah terhadap penyakit bercak ungu yang disebabkan oleh Alternaria porri. Konsorsium B. subtilis dan T. harzianum dalam campuran dengan serat karbon dan silika nano, dalam bentuk formulasi, diharapkan mampu meningkatkan ketahanan tanaman padi terhadap penyakit blas.

\section{BAHAN DAN METODE}

\section{Rancangan Percobaan}

Pengujian pada tanaman padi menggunakan rancangan acak kelompok yang terdiri dari 8 perlakuan dengan 5 ulangan. Perlakuan pada biji dan bibit padi yaitu aplikasi antagonis sebagai berikut:

$\begin{array}{ll}\text { A } & \text { B. subtilis } \\ \text { B } & \text { B. subtilis + serat karbon + silika nano } \\ \text { C } & \text { T. harzianum } \\ \text { D } & \text { T. harzianum + serat karbon + silika } \\ & \text { nano } \\ \text { E } & \text { B. subtilis + T. harzianum } \\ \text { F } & \text { B. subtilis + T. harzianum + serat } \\ & \text { karbon + silika nano } \\ \text { G } & \text { serat karbon + silika nano } \\ \text { H } & \text { Kontrol (aquades) }\end{array}$

Aplikasi antagonis dilakukan dengan menggunakan formulasi 5\% serat karbon 80 mesh dan $1 \%$ silika nano, serta kerapatan B. subtilis $10^{8}$ $\mathrm{cfu} / \mathrm{ml}$ dan $T$. harzianum $10^{8} \mathrm{spora} / \mathrm{ml}$. Data dianalisis secara statistik dengan ANOVA menggunakan program SPSS 25. Apabila terdapat perbedaan pengaruh perlakuan, maka dilakukan uji lanjut dengan Uji Jarak Berganda Duncan pada taraf nyata $5 \%$.

\section{Pembuatan Formulasi}

Formulasi biopestisida terdiri dari bahan aktif berupa bakteri B. subtilis (koleksi N. Istifadah, Laboratorium Fitopatologi, Universitas Padjadjaran) dengan kerapatan $10^{8} \mathrm{cfu} / \mathrm{ml}$ dan jamur T. harzianum (koleksi Laboratorium Fitopatologi, Universitas Padjadjaran) dengan kerapatan $10^{8} \mathrm{spora} / \mathrm{ml}$, serta bahan pembawa berupa serat karbon 80 mesh dan bahan tambahan berupa silika nano (diperoleh dari Functional Nano Powder Centre of Excellence/ FiNder CoE, Universitas Padjadjaran). Pencampuran dilakukan dengan menambahkan suspensi bakteri dan jamur pada campuran serat karbon dan silika nano sesuai dengan perlakuan (Hersanti dkk., 2019).

\section{Pembuatan Suspensi $P$. oryzae}

Jamur P. oryzae ras 173 (isolat asal Balai Penelitian Padi di Muara, Bogor) diperbanyak pada medium Oat Meal Agar (OMA) untuk mendapatkan konidia $P$. oryzae. Biakan pada medium OMA diinkubasi pada suhu ruang selama 10 hari. Kegiatan perbanyakan dilakukan secara aseptik di dalam Laminar Air Flow (LAF), yaitu dengan cara mengambil biakan murni $P$. oryzae menggunakan cork borer, lalu diletakkan pada permukaan medium OMA yang ada di dalam cawan petri. Setelah 10 hari, biakan jamur tersebut dipanen dengan cara menambahkan akuades steril + streptomisin 0,2 g/l pada cawan petri untuk mencegah kontaminasi bakteri. Kemudian biakan tersebut digosok dengan menggunakan kuas steril, untuk memisahkan biakan jamur dari medium agar. Cawan petri dibiarkan terbuka selama 2 hari pada suhu $28^{\circ} \mathrm{C}$ dalam inkubator dengan lampu TL 20 watt untuk merangsang sporulasi. Pada hari ke-12, biakan digosok menggunakan larutan $0,1 \%$ Tween 20 sebagai perata. Untuk inokulasi pada daun padi, kerapatan jamur $P$. oryzae $10^{5} \mathrm{spora} / \mathrm{ml}$ mampu menimbulkan gejala penyakit blas (Santoso dkk., 2019).

\section{Persiapan Benih Padi varietas Ciherang}

Varietas padi yang digunakan ialah varietas Ciherang. Sebelum tanam, benih padi direndam dalam air garam (5-6 sendok makan garam per liter air) untuk menyeleksi benih. Benih yang baik ialah benih yang tenggelam ketika direndam. Kemudian benih dibilas untuk menghilangkan kandungan garam. Setelah itu benih padi direndam pada air bersih selama 2 hari dan ditiriskan selama 1 hari.

\section{Aplikasi Antagonis pada Tanaman Padi}

Sepuluh biji padi yang akan disemai direndam dalam $10 \mathrm{ml}$ formulasi Agen Pengendali Hayati (APH) selama 30 menit, agar APH dapat mengoloni benih yang akan ditanam. Benih yang sudah diberi perlakuan dikecambahkan di wadah persemaian. Sisa rendaman suspensi APH $( \pm 10 \mathrm{ml})$ dituangkan secara merata di atas media tanam pada baki persemaian. Benih padi disemai pada media tanah dan kompos dengan perbandingan 2:1. Penyiraman dilakukan sebanyak 3 kali sehari. Setelah 14 hari, bibit padi dipindahtanamkan. 
Bibit padi dipindahtanamkan pada ember yang berisi tanah dan kompos dengan perbandingan 2:1, dengan ketinggian $3 / 4$ dari tinggi ember, dengan kondisi air macak-macak. Sebelum dipindahtanamankan, bagian akar bibit padi yang sudah dibersihkan dengan air, direndam dalam $10 \mathrm{ml}$ formulasi APH selama 30 menit, 2 bibit dalam $10 \mathrm{ml}$ formulasi. Satu ember diisi dengan 2 bibit yang diletakkan pada lubang tanam sedalam $4 \mathrm{~cm}$. Sisa formulasi APH hasil perendaman bibit $( \pm 10 \mathrm{ml})$ disiramkan pada media tanam secara merata.

\section{Inokulasi $P$. oryzae}

Inokulasi $P$. oryzae dilakukan ketika tanaman padi memunculkan daun ke-5 atau ketika padi berumur 15 hari. Inokulasi dilakukan dengan cara menyemprotkan suspensi spora $P$. oryzae $\left(2,75 \times 10^{5}\right.$ spora/ml) ke daun padi, menggunakan sprayer bertekanan tinggi, hingga daun padi terbasahi dengan suspensi $P$. oryzae. Tanaman padi yang telah diinokulasi ditutup plastik untuk meningkatkan kelembaban, agar $P$. oryzae dapat menginfeksi tanaman. Penyiraman dilakukan secara rutin agar kelembaban tetap tinggi. Plastik dibuka setelah terlihat gejala penyakit pada daun padi, yaitu pada 6 hsi (hari setelah inokulasi).

Pemupukan susulan dilakukan 3 kali selama musim tanam yaitu pada 14 hst (hari setelah tanam), 26 hst dan 36 hst agar tanaman uji tidak kekurangan unsur hara. Pupuk yang digunakan adalah pupuk urea 2,4 g/pot (300 kg/ha), SP-36 dan KCl masingmasing sebanyak $0,8 \mathrm{~g} /$ pot (100 kg/ha) sesuai dengan dosis anjuran penggunaan hara spesifik lokasi (PHSL) Kecamatan Jatinangor.

\section{Pengamatan}

Pengamatan gejala penyakit blas dilakukan setiap hari sejak inokulasi, untuk menghitung masa inkubasi, yaitu jangka waktu sejak inokulasi hingga terlihat gejala penyakit. Pengamatan luas gejala penyakit dilakukan dua kali seminggu untuk menghitung Intensitas Penyakit (IP) blas. IP dihitung dengan rumus dan skala kerusakan yang tertera pada Suganda dkk. (2016).

Keterangan:

$$
\mathrm{IP}=\frac{\sum\left(n_{i} x v_{i}\right)}{N x V} \times 100 \%
$$

IP: Intensitas Penyakit (\%)

$n_{i}$ : Jumlah tanaman atau bagian tanaman dengan skala kerusakan ke-i $v_{i}$ : Nilai skala i kerusakan tanaman atau bagian tanaman

$\mathrm{N}$ : Jumlah tanaman atau bagian tanaman yang diamati

V: Nilai skala kerusakan tertinggi

Nilai skala kerusakan yang digunakan ialah sebagai berikut:

$0=$ Daun sehat

$1=1-20 \%$ permukaan daun bergejala

$2=21-40 \%$ permukaan daun bergejala

$3=41-60 \%$ permukaan daun bergejala

$4=61-80 \%$ permukaan daun bergejala

$5=81-100 \%$ permukaan daun bergejala

Data IP digunakan untuk menghitung Area Under Disease Progress Curve (AUDPC). Rumus AUDPC (Campbell and Madden, 1990) adalah:

$$
\text { AUDPC }=\sum_{i}^{n-1}\left(\frac{y_{i}+y_{i+1}}{2}\right)\left(t_{i+1}-t_{i}\right)
$$

\section{Keterangan:}

$\mathrm{Y}_{\mathrm{i}+1} \quad$ : data pengamatan $\mathrm{ke}-\mathrm{i}+1$

$\mathrm{Y}_{\mathrm{i}} \quad$ : data pengamatan ke-i

$\mathrm{T}_{\mathrm{i}+1} \quad$ : waktu pengamatan $\mathrm{ke}-\mathrm{i}+1$

$\mathrm{T}_{\mathrm{i}} \quad$ : waktu pengamatan ke-i

Data AUDPC yang diperoleh digunakan untuk menghitung penghambatan penyakit pada setiap perlakuan dengan menggunakan rumus:

$$
\text { Penghambatan }=1-\frac{\text { AUDPC }_{\text {perlakuan }}}{\text { AUDPC }_{\text {kontrol }}} \times 100 \%
$$

\section{Tinggi tanaman dan jumlah anakan}

Pengamatan tinggi tanaman dan jumlah anakan bertujuan untuk mengetahui respon tanaman padi terhadap perlakuan yang diberikan. Pengamatan tinggi tanaman dilakukan dengan cara mengukur tinggi tanaman dari pangkal batang hingga ujung daun tertinggi. Jumlah anakan dihitung per rumpun. Pengamatan ini dilakukan seminggu sekali, sejak tanam hingga tanaman memasuki fase vegetatif akhir di mana tinggi tanaman dan jumlah anakan mencapai titik stagnan (tidak akan bertambah lagi).

\section{HASIL DAN PEMBAHASAN}

\section{Masa inkubasi penyakit blas}

Masa inkubasi adalah waktu yang dibutuhkan patogen sejak menginfeksi tanaman inang hingga gejala khas penyakit dapat terlihat (Sulistyarsi dkk., 2016). Gejala penyakit blas daun pada tanaman padi diawali dengan munculnya titik-titik kecil berwarna hijau keabuan yang kemudian bersatu menimbulkan bercak. Gejala bercak yang muncul berbentuk belah 
ketupat dengan tepi berwarna coklat dan bagian tengah berwarna putih keabu-abuan (Yulianto, 2017).

Pada percobaan ini gejala blas mulai terlihat pada 5-6 hsi. Gejala awal penyakit blas yang muncul pada percobaan ini dimulai dengan munculnya titiktitik kecil berwarna hitam yang kemudian titik-titik tersebut melebar dan membentuk bercak dengan bagian tengah berwarna putih dan tepinya berwarna coklat. Gambar 1 menunjukkan gejala awal penyakit blas pada perlakuan kontrol $(\mathrm{H})$ dan pada perlakuan formulasi.
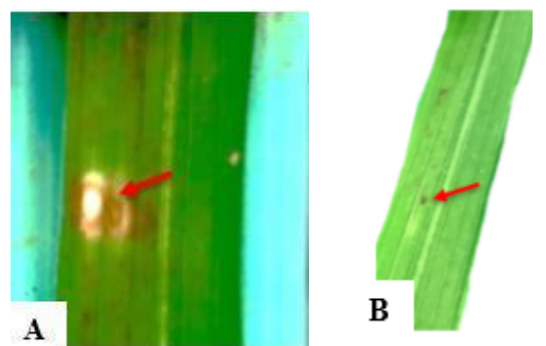

Gambar 1. Gejala blas (P. oryzae). (A) pada daun perlakuan kontrol dan (B) pada daun perlakuan formulasi

Perbedaan bentuk bercak yang muncul pada perlakuan kontrol $(\mathrm{H})$ dengan perlakuan formulasi (A-G) menandakan perbedaan ketahanan tanaman terhadap penyakit blas. Menurut Akhsan \& Palupi (2015) penyakit blas pada tanaman padi yang rentan akan berbentuk bercak dengan bagian tengah berwarna abu-abu dengan tepi yang tidak jelas dan berwarna cokelat serta dikelilingi oleh warna kuning (halo), sedangkan pada tanaman yang tahan bercak tidak berkembang dan bentuknya seperti titik kecil.

Masa inkubasi penyakit blas pada tanaman padi di setiap perlakuan yaitu 5-6 hsi atau 29-30 hst (Tabel 1). Hal ini sesuai dengan yang dinyatakan oleh Nandy et al. (2010) bahwa masa inkubasi penyakit blas pada suhu $25-30^{\circ} \mathrm{C}$ berkisar antara 5-6 hari. Setiap perlakuan pada percobaan ini tidak menyebabkan bertambahnya masa inkubasi penyakit blas pada tanaman padi. Hal ini menunjukkan $P$. oryzae masih mampu melakukan infeksi sekalipun terdapat agens antagonis pada tanaman padi. Cara dan waktu aplikasi agens antagonis pada tanaman berpengaruh terhadap kemampuannya menghambat infeksi patogen. Aplikasi B. subtilis pada benih dan $T$. harzianum pada media tanam merupakan cara yang paling efektif untuk menekan penyakit rebah kecambah pada tanaman cabai. Ketepatan cara aplikasi APH harus diperhatikan karena akan berpengaruh terhadap kerapatan dan kemampuan APH dalam menekan perkembangan penyakit. Bakteri B. subtilis yang diaplikasikan pada benih mampu mengoloni benih dan kerapatannya dapat meningkat sehingga tetap efektif dalam menekan patogen tanaman, namun apabila diaplikasikan pada media tanam kerapatan B. subtilis akan menurun dalam 30 hari setelah aplikasi. Kerapatan $T$. harzianum yang diaplikasikan pada media tanam akan konstan selama 30 hari sehingga tetap efektif dalam menekan patogen tanaman (Abeysinghe, 2009).

Tabel 1. Masa inkubasi penyakit blas

\begin{tabular}{lll}
\hline & \multicolumn{1}{c}{ Perlakuan } & Rata-rata (hsi) \\
\hline A & B. subtilis & 5,6 \\
\hline B & B. subtilis + serat karbon 5\% + silika nano 1\% & 5,8 \\
\hline C & T. harzianum & 5,8 \\
\hline D & T. harzianum + serat karbon 5\% + silika nano 1\% & 5,6 \\
\hline E & B. subtilis + T. harzianum & 5,8 \\
\hline F & B. subtilis + T. harzianum + serat karbon 5\% + silika nano 1\% & 6,0 \\
\hline G & serat karbon 5\% + silika nano 1\% & 5,6 \\
\hline H & Kontrol (aquades) & 5.6 \\
\hline
\end{tabular}

\section{Intensitas penyakit blas pada tanaman padi}

Intensitas penyakit blas menggambarkan keparahan penyakit yang diukur per rumpun padi. Pengukuran ini bertujuan untuk mengetahui tren tingkat keparahan penyakit blas pada tanaman padi sejak awal munculnya gejala hingga tanaman padi memasuki fase vegetatif akhir. Besar kecilnya intensitas serangan penyakit pada suatu tanaman dipengaruhi laju perkembangan penyakit pada musim tanam tersebut. Semakin tinggi intensitas 
serangan penyakit, maka semakin banyak sumber inokulum sekunder yang dapat menginfeksi tanaman, sehingga keparahan penyakit akan meningkat (Agrios, 2005). Menurut Suganda (2001) semakin rendah intensitas penyakit, berarti perlakuan tersebut efektif untuk menekan perkembangan patogen.

Intensitas penyakit blas meningkat seiring waktu (Gambar 2). Peningkatannya pada semua perlakuan lebih besar setelah padi berumur $23 \mathrm{hsi}$, terutama pada perlakuan kontrol. Perkembangan penyakit blas pada setiap perlakuan formulasi lebih rendah dibandingkan dengan kontrol, karena APH yang digunakan mampu menekan perkembangan penyakit blas, serta bahan pembawa dan bahan tambahan yang digunakan tidak melemahkan APH. Aplikasi gabungan $B$. subtilis dan $T$. harzianum tidak menyebabkan perbedaan intensitas penyakit dengan aplikasi mikroba secara tunggal. Hal ini sejalan dengan penelitian Ali \& Nadarajah (2014) bahwa aplikasi beberapa species Trichoderma spp. dengan $B$. subtilis menghasilkan penekanan perkembangan penyakit blas yang tidak berbeda nyata dengan aplikasi B. subtilis secara tunggal.

Peningkatan perkembangan penyakit blas lebih tinggi ketika padi berumur 46-53 hst (23-30 hsi). Hal ini sejalan dengan hasil penelitian Yayuk dkk. (2005) bahwa perkembangan penyakit blas daun pada tanaman padi akan terjadi secara signifikan ketika padi berumur 45-60 hst dengan laju perkembangan penyakit sebesar 0,09 unit/hari. Perkembangan penyakit blas terjadi karena adanya faktor lingkungan yang mendukung perkembangan penyakit, yaitu kelembapan yang tinggi di areal pertanaman karena pertumbuhan tanaman yang semakin rapat.

Silika nano yang digunakan sebagai bahan tambahan pada formulasi ini dapat menekan perkembangan penyakit blas. Silika nano mampu mempertebal dinding sel tanaman sehingga ketahanan tanaman terhadap penyakit blas meningkat. Menurut Heine et al. (2007) penggunaan silika mampu menurunkan intensitas penyakit busuk daun yang disebabkan oleh Phytium aphanidermatum pada tanaman paria. Penekanan setiap perlakuan terhadap penyakit blas pada tanaman padi dapat diketahui dengan menganalisis AUDPC. Nilai AUDPC diperoleh dari perkembangan penyakit pada setiap interval waktu pengamatan. Semakin kecil nilai AUDPC, maka semakin baik penekanan terhadap penyakit blas (Suganda, 2001).

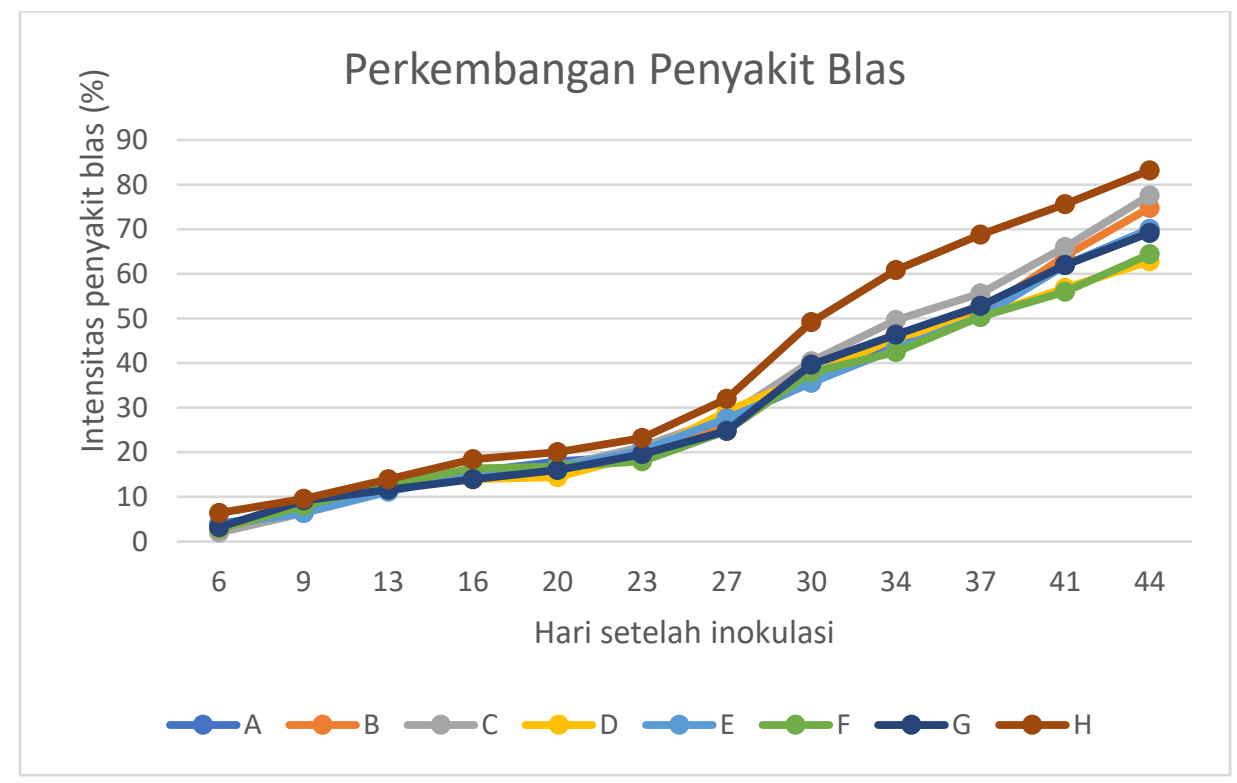

Gambar 2. Intensitas Penyakit Blas pada Berbagai Perlakuan.

Keterangan: $\mathrm{A}=$ B. subtilis, $\mathrm{B}=$ B. subtilis + serat karbon + silika nano, $\mathrm{C}=T$. harzianum, $\mathrm{D}=T$. harzianum + serat karbon + silika nano, $\mathrm{E}=$ B. subtilis + T. harzianum, $\mathrm{F}=$ B. subtilis + T. harzianum + serat karbon + silika nano, $\mathrm{G}=$ serat karbon+ silika nano, $\mathrm{H}=$ kontrol 

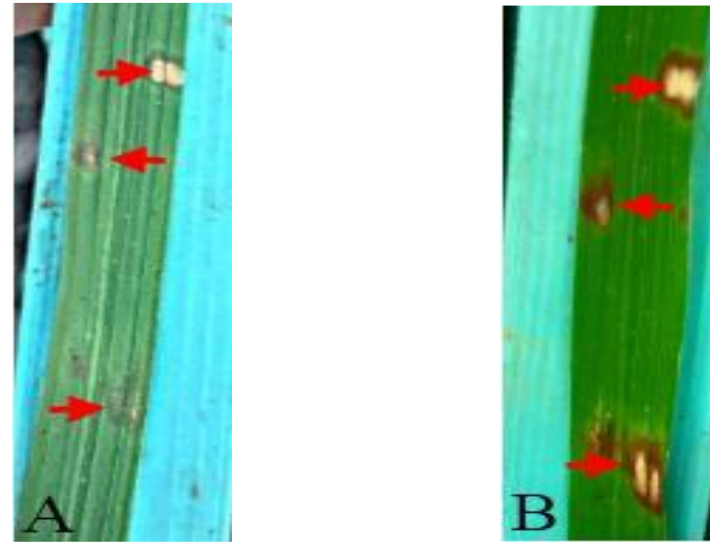

Gambar 3. Perkembangan penyakit blas (A) pada daun perlakuan kontrol 9 hsi dan (B) pada daun perlakuan kontrol 12 hsi.

Berdasarkan hasil analisis (Tabel 2) dapat dilihat bahwa nilai AUDPC semua perlakuan formulasi berbeda nyata dengan perlakuan kontrol.
Setiap perlakuan formulasi, baik menggunakan serat karbon dan silika nano ataupun tidak, menimbulkan AUDPC yang tidak berbeda nyata satu sama lain. Penekanan perkembangan penyakit blas oleh $B$. subtilis dan $T$. harzianum, tanpa serat karbon dan silika nano, secara tunggal maupun kombinasi, berkisar 15,64\% - 21,59\%. Aplikasi APH dengan formulasi serat karbon $5 \%$ dan silika nano $1 \%$ menyebabkan persentase penghambatan sebesar $18,75 \%$ - 25,12\%, yang lebih besar daripada aplikasi tanpa serat karbon dan silika nano, kecuali perlakuan B. subtillis. Perlakuan serat karbon $5 \%$ dan silika nano 1\% tanpa APH menyebabkan penghambatan perkembangan penyakit blas sebesar 19,79\%. Hal ini menunjukkan bahwa silika juga berperan dalam meningkatkan ketahanan tanaman padi terhadap infeksi P. oryzae. Adanya penghambatan perkembangan penyakit menunjukkan bahwa semua perlakuan formulasi mampu meningkatkan ketahanan tanaman padi terhadap blas.

Tabel 2. Nilai AUDPC dan penghambatan penyakit blas

\begin{tabular}{lllc}
\hline \multicolumn{1}{c}{ Perlakuan } & AUDPC & $\begin{array}{c}\text { Penghambatan } \\
\text { (\%) }\end{array}$ \\
\hline A & B. subtilis & 1131,60 a & 20,59 \\
\hline B & B. subtilis + serat karbon 5\% + silika nano 1\% & 1158,00 a & 18,75 \\
\hline C & T. harzianum & 1211,40 a & 15,64 \\
\hline D & T. harzianum + serat karbon 5\% + silika nano 1\% & 1105,00 a & 22,85 \\
\hline E & B. subtilis + T. harzianum & 1121,20 a & 21,59 \\
\hline F & B. subtilis + T. harzianum + serat karbon 5\% + silika nano 1\% & 1093,40 a & 25,12 \\
\hline G & Serat karbon 5\% +s nano 1\% & 1144,60 a & 19,79 \\
\hline H & Kontrol (aquades) & 1435,00 b & 0 \\
\hline Keterangan: Angka yang diikuti dengan huruf yang sama pada kolom 3, tidak berbeda nyata berdasarkan Uji Jarak \\
\multicolumn{2}{l}{ Berganda Duncan pada taraf nyata 5\%. }
\end{tabular}

APH yang digunakan pada percobaan ini mampu meningkatkan ketahanan tanaman (Tabel 2). Beberapa peneliti telah melaporkan tentang ketahanan tanaman yang terinduksi dengan aplikasi APH. Istifadah \& Hakim (2017) menyatakan bahwa T. harzianum mampu menginduksi ketahanan tanaman tomat terhadap penyakit bercak coklat (Alternaria solani). Menurut Istiqomah \& Kusumawati (2018) B.subtilis mampu menginduksi ketahanan tanaman tomat terhadap penyakit layu bakteri ( $R$. solanacearum). Selain itu, pada percobaan ini, silika nano yang digunakan sebagai bahan tambahan dalam formulasi dapat menekan perkembangan penyakit blas, karena silika dapat mempertebal epidermis tanaman, yang dapat menghambat penetrasi patogen ke dalam tanaman (Karunakaran et al., 2013).

Penghambatan yang disebabkan setiap perlakuan yang digunakan, walaupun berbeda dengan kontrol, tergolong rendah. Rendahnya tingkat penghambatan yang ditimbulkan diduga karena formulasi diaplikasikan hanya dua kali pada awal pertumbuhan padi, yaitu pada waktu tanam dan pindah tanam semai. Formulasi tidak diaplikasikan secara berulang pada fase pertumbuhan tanaman selanjutnya, sehingga populasi APH menurun. Pada percobaan ini aplikasi formulasi dilakukan dengan cara perendaman benih dan disiramkan pada media semai, serta perendaman akar bibit padi yang akan dipindahtanamkan dan aplikasi pada media tanam ketika pindah tanam. Menurut Abeysinghe (2009) $T$. 
harzianum yang diaplikasikan pada benih kerapatannya akan menurun pada 30 hari setelah aplikasi. Diduga cara aplikasi tersebut yang menyebabkan rendahnya penghambatan, karena penghambatan akibat kombinasi $B$. subtilis dan $T$. harzianum, baik dengan formulasi serat karbon dan silika nano ataupun tidak, menjadi tidak berbeda nyata dengan penghambatan akibat aplikasi mikroba secara tunggal.

\section{Tinggi tanaman dan jumlah anakan}

Data tinggi tanaman dan jumlah anakan diperoleh dari rata-rata tinggi dan jumlah anakan pada setiap perlakuan (Tabel 3). Tinggi tanaman ratarata pada 9 minggu setelah tanam di setiap perlakuan relatif sama, yaitu berkisar antara 86,3-89,6 cm. Adapun jumlah anakan pada setiap perlakuan berkisar antara 14-22 anakan per rumpun.

Tabel 3. Tinggi tanaman dan jumlah anakan padi pada 9 mst.

\begin{tabular}{llrr}
\hline & \multicolumn{1}{c}{ Perlakuan } & $\begin{array}{c}\text { Tinggi Tanaman } \\
\text { (cm) }\end{array}$ & \multicolumn{1}{c}{$\begin{array}{c}\text { Jumlah } \\
\text { Anakan }\end{array}$} \\
\hline A & B. subtilis & $89,60 \mathrm{a}$ & $15 \mathrm{a}$ \\
\hline B & B. subtilis + serat karbon 5\% + silika nano 1\% & $86,60 \mathrm{a}$ & $20 \mathrm{ab}$ \\
\hline C & T. harzianum & $86,30 \mathrm{a}$ & $22 \mathrm{ab}$ \\
\hline D & T. harzianum + serat karbon 5\% + silika nano 1\% & $88,45 \mathrm{a}$ & $14 \mathrm{a}$ \\
\hline E & B. subtilis + T. harzianum & $88,30 \mathrm{a}$ & $17 \mathrm{ab}$ \\
\hline F & B. subtilis + T. harzianum + serat karbon 5\%+ silika nano 1\% & $89,25 \mathrm{a}$ & $18 \mathrm{ab}$ \\
\hline G & serat karbon 5\% + silika nano 1\% & $87,00 \mathrm{a}$ & $19 \mathrm{ab}$ \\
\hline H & Kontrol (aquades) & $89,50 \mathrm{a}$ & $18 \mathrm{ab}$ \\
\hline
\end{tabular}

Keterangan: Angka yang diikuti dengan huruf yang sama pada kolom 3 dan 4 tidak berbeda nyata berdasarkan Uji Jarak Berganda Duncan pada taraf nyata 5\%.

Penggunaan bakteri endofit B. subtilis dan $T$. harzianum dalam percobaan ini tidak berpengaruh terhadap tinggi tanaman dan jumlah anakan tanaman padi yang terbentuk (Tabel 3). Pada semua perlakuan, tinggi tanaman dan jumlah anakan pada 9 mst tidak berbeda nyata dengan kontrol. Hal tersebut diduga karena fungsi biostimulant pada APH yang digunakan di percobaan ini belum berperan optimal. Faktor yang memengaruhi fungsi biostimulant tidak optimal ialah waktu dan kerapatan APH yang digunakan mengalami penurunan. Menurut Abeysinghe (2009) kerapatan T. harzianum dalam tanah hanya dapat bertahan selama 30 hari. Hanudin dkk. (2018) menyatakan bahwa kelompok Bacillus merupakan mikroba yang rentan apabila terkena paparan sinar matahari.

Silika nano yang digunakan pada formulasi dalam percobaan ini tidak dapat meningkatkan tinggi tanaman dan jumlah anakan tanaman padi. Hal tersebut sesuai dengan pernyataan Candra dkk. (2016) bahwa pemberian silika nano tidak memengaruhi tinggi tanaman, jumlah daun dan jumlah malai tanaman padi. Silika nano yang digunakan pada percobaan ini dapat memperkuat jaringan tanaman (anakan tanaman menjadi lebih kokoh) dan kurang berperan dalam meningkatkan komponen pertumbuhan seperti tinggi tanaman dan jumlah anakan tanaman padi hingga 67 hst. Silika nano pada tanaman padi tidak berpengaruh terhadap tinggi dan jumlah anakan tanaman padi, namun mampu menekan serangan patogen pada areal pertanaman, sehingga mengurangi kehilangan hasil tanaman padi (Candra dkk., 2019).

\section{Bobot hasil tanaman padi}

Pemanenan bulir padi dilakukan pada 103 hst. Bobot biji padi yang diperoleh dari setiap perlakuan tidak berbeda nyata, berkisar antara 12,60 gram hingga 21,80 gram atau setara dengan 3,15 ton/ha sampai 5,4 ton/ha (Tabel 4). Salah satu faktor yang memengaruhi hasil tanaman padi ialah adanya organisme pengganggu tumbuhan. Suganda dkk. (2016) menyatakan bahwa serangan blas pada varietas Ciherang di lokasi endemik dapat mengurangi hasil padi sebesar $61 \%$ atau setara dengan 3,65 ton/ha. Hal ini tidak sesuai dengan hasil percobaan ini, di mana produksi yang diperoleh pada setiap perlakuan tidak berbeda nyata, meskipun intensitas penyakit blas pada perlakuan kontrol lebih tinggi dibanding perlakuan yang lain. Hal ini diduga 
karena penyakit blas pada tanaman padi percobaan tidak mengganggu perkembangan malai tanaman padi. Tidak berkembangnya blas daun menjadi blas leher malai pada percobaan ini diduga karena kelembaban dan curah hujan pada areal pertanaman cukup rendah. Menurut Hemi \& Imura (1989) spora $P$. oryzae tidak akan terbentuk apabila kelembaban kurang dari 93\%. Infeksi blas pada leher malai terjadi apabila blas pada daun menghasilkan spora, karena perkembangan penyakit blas daun ke blas malai terjadi secara pasif dengan bantuan angin ataupun air hujan. Penurunan hasil tanaman padi dapat terjadi apabila penyakit blas daun berkembang menjadi blas leher malai. Tanaman padi yang terinfeksi blas leher malai akan membuat bulir padi yang dihasilkan kosong dan juga malai akan busuk, kering dan patah (Yulianto, 2017).

Tabel 4. Bobot biji padi yang diperoleh dari setiap perlakuan

\begin{tabular}{|c|c|c|}
\hline & Perlakuan & Bobot biji padi (g) \\
\hline A & B. subtilis & $14,80 \mathrm{a}$ \\
\hline B & B. subtilis + serat karbon $5 \%+$ silika nano $1 \%$ & $21,80 \mathrm{a}$ \\
\hline $\mathrm{C}$ & T. harzianum & $19,00 \mathrm{a}$ \\
\hline $\mathrm{D}$ & T. harzianum + serat karbon $5 \%+$ silika nano $1 \%$ & $12,60 \mathrm{a}$ \\
\hline $\mathrm{E}$ & B. subtilis + T. harzianum & $15,00 \mathrm{a}$ \\
\hline $\mathrm{F}$ & B. subtilis + T. harzianum + serat karbon $5 \%+$ silika nano $1 \%$ & $17,80 \mathrm{a}$ \\
\hline G & serat karbon $5 \%+$ silika nano $1 \%$ & $18,00 \mathrm{a}$ \\
\hline $\mathrm{H}$ & Kontrol (aquades) & $19,00 \mathrm{a}$ \\
\hline
\end{tabular}

Keterangan: Angka yang diikuti dengan huruf yang sama pada kolom 2 tidak berbeda nyata berdasarkan Uji Jarak Berganda Duncan pada taraf nyata 5\%.

\section{SIMPULAN}

Berdasarkan percobaan yang dilakukan dapat disimpulkan bahwa aplikasi $B$. subtilis dan $T$. harzianum, baik secara tunggal maupun kombinasi, mampu meningkatkan ketahanan tanaman padi terhadap penyakit blas dengan penghambatan berkisar antara 15,64\% - 21,59\%. Aplikasi B. subtilis dan T. harzianum dengan campuran dan tanpa campuran serat karbon $5 \%$ dan silika nano $1 \%$ mampu meningkatkan ketahanan tanaman padi terhadap penyakit blas, dengan penghambatan penyakit berkisar antara 18,75\% - 25,12\%. Infeksi blas daun yang tidak berkembang menjadi blas leher malai tidak berpengaruh terhadap hasil tanaman padi.

\section{DAFTAR PUSTAKA}

Abeysinghe, S. 2009. Effect of combined use of Bacillus subtilis CA32 and Trichoderma harzianum RU01 on biological control of Rhizoctonia solani on Solanum melongena and Capsicum annum. Plant Pathology Journal. 8 (1): 9-16

Agrios, GN. 2005. Plant Pathology $5^{\text {th }}$ Edition. Florida. Elsevier Academic Press. Pages 1-290
Aida, MN. 2016. Viabilitas bakteri Pseudomonas fluorescens Mig. dalam formula serat karbon 80 mesh. (Skripsi: Tidak dipublikasikan). Fakultas Pertanian Universitas Padjadjaran. Halaman 21

Akhsan, N, dan PJ Palupi. 2015. Pengaruh waktu terhadap intensitas penyakit blast dan keberadaan spora Pyricularia grisea (Cooke) Sacc. pada lahan padi sawah (Oryza sativa) di kecamatan samarinda utara. Ziraa'ah. 40 (2): 114-122

Ali, H, and K Nadarajah. 2014. Evaluating the efficacy of Trichoderma spp. and Bacillus subtilis as biocontrol agents against Magnaporthe grisea in rice. Australian Journal of Crop Science. 8 (9): 1324-1335.

Campbell, CL, and LV Madden. 1990. Introduction to Plant Disease Epidemiology. John Willey \& Sons, New York. 532 pp.

Candra, SD, Ngatimun, dan J Suhartono. 2019. Aplikasi bahan silika alami dan frekuensi pemberian nano-silika untuk meningkatkan kualitas hasil dan usahatani padi. Agrika: Jurnal Ilmu-Ilmu Pertanian. 13 (2): 177-188.

Djaenuddin, N. 2016. Interaksi Bakteri Antagonis dengan Tanaman: Ketahanan Terinduksi pada 
Tanaman Jagung. Iptek Tanaman Pangan. 11 (2): 143-148.

Grosch, R, H Johannes, M Schneider, A Kofoet, and C Feller. 2011. Impact of continous cropping of lettuce on the disease dynamics of bottom rot and genotypic diversity of Rhizoctonia solani AG 1-IB. Journal of Phytopathology. 159: 35-44

Hanudin, K Budiarto, dan B Marwoto. 2018. Potensi beberapa mikroba pemacupertumbuhan tanaman sebagai bahan aktif pupuk dan pestisida hayati. Jurnal Litbang Pertanian. 37 (2): 59-70

Heine, G, G Tikum, and W Horst. 2007. The effect of silicon on the infection by spread of Phytium aphanidermatum in single roots of tomato and bitter gourd. Journal of Experimental Botany. 58 (3): 569-577

Hemi, T and J Imura. 1989. On the relation of air humidity to conidial formation in the rice blas fungus Pyricularia oryzae and the characteristics in the germination of conidia produced by strain showing different pathogenicity. Annual Phytopathology Society Japan 9: 147-156

Hersanti, dan L Djaya. 2019. Kemampuan Trichoderma harzianum dalam formulasi serat karbon dan partikel silika nano (NPs) untuk menekan Phytophthora nicotianae. Semiloknas FKPTPI 2019 [ABSTRAK]

Hersanti, Sudarjat, dan A Damayanti. 2019. Kemampuan Bacillus subtilis dan Lysinibacillus sp. dalam silika nano dan serat karbon untuk menginduksi ketahanan bawang merah terhadap penyakit bercak ungu (Alternaria porri (Ell.) Cif). Jurnal Agrikultura. 30(1): 8-16

Istifadah, $\mathrm{N}$, dan $\mathrm{N}$ Hakim. 2017. Kemampuan kompos dan kompos plus untuk meningkatkan ketahanan tanaman tomat terhadap penyakit bercak coklat (Alternaria solani Sor.). Jurnal Agrikultura. 28 (3): 111117

Istiqomah, dan DE Kusumawati. 2018. Pemanfaatan Bacillus subtilis dan Pseudomonas fluorescens dalam pengendalian hayati Ralstonia solanacearum penyebab penyakit layu bakteri pada tomat. Jurnal Agro. 5(1): 1-12

Karunakaran, G, R Suriyaprabha, P Manivasakan, R Yuvakkumar, V Rajendran, P Prabu, and N Kanman. 2013. Effect of nanosilica and silicon sources on plant growth promoting rhizobacteria, soil nutrients and maize seed germination. IET Nanobiotechnol. 1-8

Komarwidjaja, W. 2009. Karakteristik dan pertumbuhan konsorsium mikroba lokal dalam media mengandung minyak bumi. Jurnal Teknologi Lingkungan 10(1): 114-119.

Nandy, S, N Manda, PK Bhowmik, MS Khan, and SK Basu. 2010. Sustainable management of rice blast (Magnaporthe grisea (Habbert) Bar): 50 years of research progress in molecular biology. In Arya and A. E. Parello (Eds.) Management of Fungal Plant Pathogens. CAB International. P. 92-106

Nawangsih, AA, E Wijayanti, dan JG Kartika. 2015. Pengembangan formulasi biopestisida berbahan aktif bakteri Staphylococcus epidermis dan Bacillus subtilis untuk mengendalikan penyakit layu bakteri oleh Ralstonia solanacearum pada tomat. Prosiding Seminar Nasional Perlindungan Tanaman II hal: 97-103

Parida, I, TA Damayanti, dan Giyanto. 2016. Isolasi, seleksi dan identifikasi bakteri endofit sebagai agens penginduksi ketahanan padi terhadap hawar daun bakteri. Jurnal Fitopatologi Indonesia. 12 (6): 199-208.

Ruhyaman, RR, Hersanti, S Hartati, M Setiawati, and IM Joni. 2017. Efficacy of Bacillus subtilis in nano silica and carbon fiber formulation for control of Ralstonia solanacearum under in vitro conditions. [Abstrak]. $5^{\text {th }}$ Asian PGPR International Conference for Sustainable Agriculture. Pp. 142

Santoso, A Nasution, DW Utami, I Hanarida, AD Ambarwati, S Moeljoprawiro, dan D Tharreau. 2007. Variasi genetik dan spektrum virulensi patogen blas pada padi asal Jawa Barat dan Sumatera. Penelitian Pertanian Tanaman Pangan. 26(3): 151-155

Santoso, S Sipi, Subiadi, dan A Nasution. 2019. Keragaman ras Pyricularia grisea penyebab penyakit blas pada tanaman padi sawah papua barat. Penelitian Pertanian Tanaman Pangan. 3 (1): 1-8.

Sreedevi, B, MC Devi and DVR Saigopal. 2011. Induction of defense enzymes in Trichoderma harzianum treated groundnut plants Against Macrophomina phaseolina. Journal of Biological Control. 25 (1): 33-39.

Suganda, T. 2001. Penginduksian resistensi tanaman kacang tanah terhadap penyakit karat (Puccinia arachidis Speg.) dengan 
pengaplikasian asam salisilat, asam asetat etilendiamintetra, kitin asal kulit udang, air perasan daun melati, dan dikaliumhidrogenfosfat. Jurnal Agrikultura. 12 (2): 83-88

Suganda, T, E Yulia, F Widiantini, dan Hersanti. 2016. Intensitas penyakit blas (Pyricularia oryzae Cav.) pada padi varietas ciherang di lokasi endemik dan pengaruhnya terhadap kehilangan hasil. Jurnal Agrikultura. 27 (3):154-159.

Sulistyarsi, A, Pujiati, dan MWArdhi. 2016. Pengaruh konsentrasi dan lama inkubasi terhadap kadar protein crude enzim selulase dari kapang Aspergillus niger. Proceeding Biology Education Conference. 13 (1): 781-786
Wang X, S Lee, J Wan, J Ma, T Bianco, and Y Jia. 2014. Current advances on genetic resistance to rice blast disease. Intechopen Chapter 7: 195-217.

Yayuk, A Bety, SY Jatmiko, dan BP Ismail. 2005. Ketahanan genotip dan perkembangan penyakit pada padi sawah tadah hujan. Penelitian Pertanian Tanaman Pangan. 24 (1): 33-39.

Yulianto. 2017. Pengendalian penyakit blas secara terpadu pada tanaman padi. Iptek Tanaman Pangan. 12 (1): 25-33.

Zhang, J, F Shao, Y Li, H Cui, H Li, Y Zou, C Long, L Lan, J Chai, S Chen, X Tang, and JM Zhou. 2007. A Pseudomonas syringae effector inactivates MAPKs to suppress PAMPinduced immunity in plants. Artikel Cell Host \& Microbe. 1: 175-185. 